\title{
EVALUATION OF ANTIMICROBIAL AND ANALGESIC ACTIVITY OF DIPLOCYCLOS PALMATUS FRUITS ON ALBINO MICE
}

\author{
RAM KISHAN J ${ }^{1}$, KHAJA ZEEYAUDDIN ${ }^{2}$, VENKANNA ${ }^{1}{ }^{1}$, SATEESH KUMAR VEMULA ${ }^{3 *}$ \\ ${ }^{1}$ Department of Pharmacognosy, MAK College of Pharmacy, Moinabad-Ranga Reddy-Hyderabad, Telangana, India. ${ }^{2}$ Department of \\ Pharmacology, MAK College of Pharmacy, Moinabad-Ranga Reddy-Hyderabad, Telangana, India. ${ }^{3}$ Department of Pharmaceutics, MAK \\ College of Pharmacy, Moinabad-Ranga Reddy-Hyderabad, Telangana, India. Email: vemulasatish15@gmail.com
}

Received: 07 July 2018, Revised and Accepted: 28 September 2018

ABSTRACT

Objective: The present study is preplanned to assess the antimicrobial and analgesic activity of the collected plants of Diplocyclos palmatus from Moinabad, Ranga Reddy, Telangana.

Methods: In this study, D. palmatus fruits were used to gain the ethanolic extract and were tested for the phytochemical screening, antimicrobial activity using agar diffusion method against Gram-negative bacteria (Escherichia coli) and Gram-positive (Bacillus) and to compare its effect with the marketed standard streptomycin, ciprofloxacin, and analgesic activity of plant was performed by tail clip, tails immersion, and radiant heat method.

Results: The maximum zone of inhibition is shown in the Gram-negative bacteria (E. coli) compared to standard and control. The ethanolic extract of D. palmatus fruits was shown analgesic activity and it was found to be more remarkable when compared to the standard aspirin and control. From the results of three different methods at different dose of ethanolic extract ( $100 \mathrm{mg} / \mathrm{kg}, 200 \mathrm{mg} / \mathrm{kg}, 400 \mathrm{mg} / \mathrm{kg}$ followed by $0-5 \mathrm{~min}$ interval up to $30 \mathrm{~min}$ ), tail immersion method at $200 \mathrm{mg} / \mathrm{kg}$ dose of the D. palmatus fruits extract was achieved good results i.e., in $10 \mathrm{~min}(11.4 \pm 1.93)$ and $15 \mathrm{~min}(13.4 \pm$ 1.63). In tail clip method, $400 \mathrm{mg} / \mathrm{kg}$ dose is in $10 \mathrm{~min}(11 \pm 1.67)$ and $15 \mathrm{~min}(10 \pm 0.707)$ achieved best output, while same thing radiant heat method $200 \mathrm{mg} / \mathrm{kg}$ dose of the D. palmatus fruits extract is in $10 \mathrm{~min}(11.3 \pm 1.67)$ and $15 \mathrm{~min}(14 \pm 1.82)$ achieved outstanding results.

Conclusion: The analgesic and antimicrobial activity of ethanolic extract of $D$. palmatus fruits are more significant compared to the other part of D. palmatus. Hence, the study concludes that the plant is having both analgesic and antimicrobial activity, and therefore, it can be used for various therapeutic purposes and further analysis.

Keywords: Analgesic activity, Antimicrobial activity, Diplocyclos palmatus, Ethanolic extract, Streptomycin, Ciprofloxacin, Aspirin.

(c) 2019 The Authors. Published by Innovare Academic Sciences Pvt Ltd. This is an open access article under the CC BY license (http://creativecommons. org/licenses/by/4. 0/) DOI: http://dx.doi.org/10.22159/ajpcr.2019.v12i2.28346

\section{INTRODUCTION}

The medicinal plants are widely used by the traditional medicinal practitioners for curing various diseases in their day-to-day practice. In traditional system of medicine, different parts of Diplocyclos palmatus were used. It is a short-lived, perennial climbing plant producing annual, much-branched stems up to $6 \mathrm{~m}$ long from a fleshy rootstock [1]. The stems scramble over the ground, climbing into the surrounding vegetation where it attaches itself by means of tendrils. It is more commonly known as the lollipop climber or striped cucumber (E), Shivalingi (H) belonging to family Cucurbitaceae. The plant is recorded in India as growing and spreading in the wild. When ripe, it is red with longitudinal white stripes and reminds one of lollipop, hence, the common name. Lollipop climber is a perennial climber with hairless stem, becoming thickened and white dotted on the ridges when older. Leaves are broadly ovate, $3.5-14 \mathrm{~cm} \times 4-14.5 \mathrm{~cm}$, lobes are linear shaped to elliptic, hairless. Leaf stalk $1.5-9.0 \mathrm{~cm}$ long. Flowers are small, white or yellowish, male in stalkless clusters of 2-8, along with five female flowers in the same axial. Sepal cup is 3-4 mm long in male, 1.5-2.5 mm long in female, sepals smaller than tube. Flower of male larger than female. Fruit is solitary. It is ovoid round, $1.5-2.5 \mathrm{~cm}$. When ripe, it is red with longitudinal white stripes and reminds one of lollipop, hence, the common name. It is found including the Himalayas, at altitudes of 200-1500 m. The small flowers of Lingini or Shivalingi are of greenish-yellow in color. The female flowers of the plant are borne in fascicles and the male ones are solitary. The plant's corolla is about 3-4 $\mathrm{mm}$, with ovate-oblong, acute, pubescent lobes. The fruit or berry of the plant is rounded, with a diameter of $2-3 \mathrm{~cm}$ and the bluish-green. They ripe red and bear a few brown, obovate seeds. The compressed seeds have a length of $4 \mathrm{~mm}$ and width of $3 \mathrm{~mm}$, and they are usually encircled by a prominent raised band. The plant is generally flowers between the months of August and September and fruits in September and October in central India [2].

Phytochemical studies of D. palmatus show the presence of alkaloids, flavonoids, triterpenoid saponins, steroids and proteins, and resins with sugars and starch. The seeds have been reported to contain $12 \%$ oil, protein, along with goniothalamin, bryonin, punicic acid, and lipids. Disease and illness are very much related and having similar concepts. The concepts are mainly, patients suffer from "illnesses" and physician diagnoses and treats "diseases." Disease can refer to a combination of signs and symptoms. It can also be referred as a phenomenon associated with a disorder of function or structure or illness associated with a specific cause [3].

D. palmatus traditionally reported as an antimicrobial properties and analgesic properties, scientifically seed and leaves of plant already reported as an antimicrobial and analgesic activity. In the present study, fruits of D. palmatus are studied for phytochemical screening, antimicrobial, and analgesic activity. Seeds are used in sterility due to blocked tubes in women, snake bite, root fever, stomach ache, and external abscess. Fruits are used in diarrhea; the Indian women sometimes take the seeds in combination with other plant drugs for helping conception and prevent miscarriage. The practitioners of ayurvedic medicine use the plant's fruit as an aphrodisiac and tonic, while in Siddha, the entire plant is used for getting relief from constipation. In vitro studies revealed that D. palmatus (aerial part) contain antioxidant and antimicrobial activity; seeds have analgesic, 
anti-inflammatory, and antiarthritic activity. In vivo anticonvulsant activity of leaves was also reported [4]. D. palmatus was identified and authenticated by Botanical Survey of India, Deccan Regional Centre - Hyderabad, belonging to the family Cucurbitaceae [5-7].

\section{MATERIALS AND METHODS}

\section{Plant materials}

The fresh fruits of D. palmatus were collected from Moinabad rural area, Ranga Reddy district in the month of November 2016. Plant was identified and authenticated by Botanical Survey of India, Deccan Regional Centre, Hyderabad, belonging to the family Cucurbitaceae.

\section{Chemical and reagents}

Chemicals reagents were purchased from S.D Fine and Merck Chemicals (Mumbai, India). Albino mice were purchased from Sanzyme animal house, Gaganpahad, Hyderabad, Telangana - 500 077. Animal studies were performed in MAK College of Pharmacy, Moinabad. The organisms Escherichia coli (Gram-negative) bacteria and Bacillus subtilis (Grampositive) were obtained from soil of MAK College of Pharmacy by isolation technique. Aspirin, streptomycin, and ciprofloxacin were purchased from local medical shop.

\section{Instrumentation}

Autoclave, Soxhlet apparatus, Petri dish, heating mantle, incubator, mice cage, hot air oven, laminar air flow, analgesiometer, water bath glass, etc., were obtained from MAK College of Pharmacy.

\section{Preparation of extract}

The fruits of the plant are shade, dried, and powdered. The extraction of powdered fruits was performed by hot extraction method by Soxhlet apparatus using ethanol. The extract was then filtered respectively through Whatman filter paper to remove impurities and volume is reduced by vacuum evaporator and then dried, collected, and finally stored in well-closed container at room temperature until it is used for further studies in this experiment [8-10].

\section{Test microorganism}

The test microorganisms were clinical isolates from the stock culture of MAK College of Pharmacy, Moinabad, Ranga Reddy. They include E. coli (MTCC 1698) and B. subtilis (MTCC 2757). Each of these microorganisms was subcultured into nutrient broth to test for viability and subsequently on nutrient agar slants and kept at $4^{\circ} \mathrm{C}$ before susceptibility testing.

\section{Animals}

To study the analgesic and anti-inflammatory activity of the extract, male and female albino mice were used in the present study. In the present study, male and female albino mice were used. The animals were maintained in clean polypropylene cages with $12 \mathrm{~h}$ light and dark cycle at a temperature of $26-28^{\circ} \mathrm{C}$ and supplied with pellet diet and water ad libitum. The animals were acclimatized to laboratory conditions for 1 week before starting the experiment. The experimental protocol approved by the Institutional Animal Ethical Committee allotted registration No. 1970/PO/RE/S/17/CPCSEA.

\section{Phytochemical screening}

The phytochemical investigation of ethanolic and aqueous extracts of D. palmatus fruits was carried out by various standard procedures for the detection of secondary metabolite such as of alkaloids, tannins, flavonoids, and triterpenoids. Thin-layer chromatography (TLC) was also performed for bryonin and punicic acid (identified as active components) using mobile phase of acetone: toluene:ethyl acetate $(1: 1: 1)[10,11]$.

\section{Determination of antimicrobial activity}

In vitro antimicrobial screening was done by agar diffusion method for the primary selection of the compound as therapeutic agent. The antimicrobial activity of D. palmatus fruit extract was performed against two pathogenic bacteria such as B. subtilis (Gram-positive) and E. coli (Gram-negative). The direct colony suspension method was used for inoculates preparation. Streptomycin and ciprofloxacin were used as the standard drug for comparative purposes with the extract. Stock solution of the standard drug was prepared in sterile distilled water to give a concentration of $100 \mathrm{mg} / \mathrm{ml}$, and the test extracts were also prepared at the same concentration. Sterile discs ( $0.5 \mathrm{~mm}$ diameter) on Petri dish were dipped into the test extract and were put onto the agar surface after complete drying. Plates were incubated at $35^{\circ} \mathrm{C}$ for $24 \mathrm{~h}$. After incubation, plates were observed for zones of inhibition, and their diameter was measured including the diameter of the disc [12-14].

\section{Determination of analgesic activity}

Haffner's tail clip method

In this method, the raised tail phenomena in mice are observed. Five mice per group are used. A clip is applied to the base of the tail of mice and the reaction time is noted. The test compounds are administered orally to fasted animals. The animal quickly responds to the stimuli by biting the clip or the tail near the location of the clip. The time between stimulation onset and response is measured by a stopwatch $[10,15,16]$.

\section{Tail immersion test}

This method is based on observations that morphine-like drugs are selectively capable of prolonging reaction time of the typical tail withdraw reflex in mice induced by immersing the end of the tail in warm water of $55^{\circ} \mathrm{C}$. The mice are placed in individual cages leaving the tail hanging out freely. The animals can adapt the cages for $30 \mathrm{~min}$ before testing. The lower $5 \mathrm{~cm}$ portion of tail is marked. This part of tail is immersed in a cup of freshly filled water of exactly $55^{\circ} \mathrm{C}$ within a few

Table 1: Preliminary phytochemical study of Diplocyclos palmatus fruits

\begin{tabular}{lll}
\hline $\begin{array}{l}\text { Phytochemical } \\
\text { constituents }\end{array}$ & $\begin{array}{l}\text { Aqueous } \\
\text { extract }\end{array}$ & $\begin{array}{l}\text { Ethanol } \\
\text { extract }\end{array}$ \\
\hline Alkaloids & Positive & Positive \\
Triterpenoids & Negative & Positive \\
Flavonoids & Positive & Negative \\
Tannins & Negative & Negative \\
Saponins & Positive & Positive \\
Sugars & Negative & Negative \\
Starch & Negative & Negative \\
Steroids & Positive & Positive \\
Proteins & Positive & Positive \\
Resins & Negative & Negative \\
\hline
\end{tabular}

Table 2: Physicochemical analysis of Diplocyclos palmatus fruits

\begin{tabular}{ll}
\hline Parameters & Values \\
\hline \% Of foreign matter & $<2$ \\
\% Of loss on drying at $105^{\circ} \mathrm{C}$ (moisture content) & 3 \\
\% Total ash content & 9.6 \\
\% Water-soluble ash & 10.27 \\
\% Acid-insoluble ash & 0.25 \\
\% Solubility at room temperature & \\
a. Ethanol & 54 \\
b. Water (cold) & 29.60 \\
Extractive values & \\
a. Pet. ether extract $60-80^{\circ} \mathrm{C}$ & 10.8 \\
b. Chloroform & 1.08 \\
c. Ethanol & 1.0 \\
$\mathrm{P}_{\mathrm{H}}$ value & 8.04 \\
\hline
\end{tabular}

seconds; mice react by withdrawing the tail. A stopwatch records the reaction time. The reaction time is determined before and periodically after oral administration of test substance. A withdrawal response of more than $6 \mathrm{~s}$ is recorded as positive response $[10,15,16]$.

\section{Radiant heat method}

This test is useful for quantitative measurements of pain threshold against thermal radiation in man and the evaluation of analgesic 
Table 3: Growth in nutrients agar containing different concentration of extract in $\mathrm{mg} / \mathrm{ml}$ (antimicrobial activity)

\begin{tabular}{|c|c|c|c|c|c|c|c|}
\hline \multirow{2}{*}{$\begin{array}{l}\text { Name of the } \\
\text { bacteria }\end{array}$} & \multirow[t]{2}{*}{ Control } & \multirow{2}{*}{$\begin{array}{l}\text { Ethanol } \\
1: 11 \mathrm{~g} / \mathrm{ml}\end{array}$} & \multirow{2}{*}{$\begin{array}{l}\text { Extract } \\
1 \mathrm{~g} / 2 \mathrm{mlmg} / \mathrm{ml}\end{array}$} & \multicolumn{2}{|c|}{ Ciprofloxacin } & \multicolumn{2}{|c|}{ Streptomycin } \\
\hline & & & & $1: 1$ & $1: 2$ & $1: 1$ & $1: 2$ \\
\hline Bacillus subtilis & Positive & Negative & Negative & Negative & Negative & Negative & Negative \\
\hline Escherichia coli & Positive & Negative & Negative & Negative & Negative & Negative & Negative \\
\hline
\end{tabular}

Table 4: Antimicrobial activity of ethanol extract of Diplocyclos palmatus fruit $(1 \mathrm{~g} / \mathrm{ml})$

\begin{tabular}{lll}
\hline Name of extract & \multicolumn{2}{l}{$\begin{array}{l}\text { Microorganism } \\
\text { (zone of inhibition in mm) }\end{array}$} \\
\cline { 2 - 3 } & $\begin{array}{l}\text { Gram- } \\
\text { positive }\end{array}$ & $\begin{array}{l}\text { Gram-negative } \\
\text { Escherichia } \\
\text { coli }\end{array}$ \\
\hline Ethanillus & 12 & 19 \\
Ethanol extract of streptomycin (1:1) & 8 & 13 \\
Ethanol extract of ciprofloxacin (1:1) & 11 & 9 \\
Ethanol extract of streptomycin (1:2) & 10 & 15 \\
Ethanol extract of ciprofloxacin (1:2) & 9 & 7 \\
Ethanol pure extract control & 8 & 15 \\
Ethanol pure extract (1:1) & 12 & 14 \\
Ethanol pure extract (1:2) & 11 & 13 \\
\hline
\end{tabular}

activity. It is very useful for discriminating between centrally acting morphine such as analgesics and non-opioid analgesics. The animal is put into a small cage with an opening for the tail at the rear wall. The investigator holds the tail gently. By the opening of the shutter, a light beam exerting radiant heat is directed at the end of the tail. For about $6 \mathrm{~s}$, the reaction of animal is observed. The mice try to pull the tail away and turn the head. The shutter is closed with a switch as soon as the investigator notices the reaction. Mice with a reaction time of $>6 \mathrm{~s}$ are not used in this test. The escape reaction is the end of the test, before administration of the test compound and the standard orally. The analgesiometer can also be used to measure analgesic activities $[10,16]$.

\section{RESULTS}

Preliminary phytochemical screening was done in aqueous and ethanolic extracts. In aqueous extracts, the presence of alkaloids, flavonoids, saponins, steroids, and proteins was observed, while triterpenoids, resins, sugar, starch, and tannins were absent. In case of ethanolic extract, the presence of alkaloids, triterpenoids, saponins, steroids, and proteins was observed while flavonoids, tannins, sugar, starch, and resins were absent. These results are summarized in Table 1. Various possible physicochemical parameters of D. palmatus were determined and reported in Table 2. TLC of bryonin and punicic acid was identified with mobile phase of acetone: toluene: ethyl acetate (1:1:1) and the Rf values were found to be 0.77 (bryonin), 0.80 (punicic acid), 0.88 , and 0.92 [11,17]. The graphical representation of TLC is showed in Fig. 1.

Growth in nutrient agar containing different concentrations of extract in $\mathrm{mg} / \mathrm{ml}$ is summarized in Table 3.

The results of antimicrobial activity of the fruit extracts against E. coli and B. subtilis are shown in Table 4.

The maximum zone of inhibition is shown in the Gram-negative bacteria (E. coli) compared to standard and control. The zone of inhibition was found to be $19 \mathrm{~mm}$ for ethanol control, $15 \mathrm{~mm}$ for ethanol pure extract, $14 \mathrm{~mm}$ for ethanol extract pure (1:1), $13 \mathrm{~mm}$ for both ethanol pure extract and ethanol extract of streptomycin (1:1), $9 \mathrm{~mm}$ for ethanol extract of ciprofloxacin (1:1) $9 \mathrm{~mm}, 15 \mathrm{~mm}$ for ethanol extract of streptomycin (1:2), and $7 \mathrm{~mm}$ for ethanol extract of ciprofloxacin (1:2). Similarly the activity against the Gram-positive bacteria (B. subtilis),

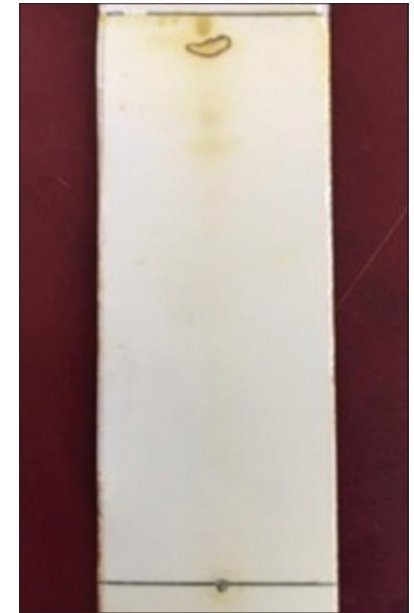

Fig. 1: Thin-layer chromatography of Diplocyclos palmatus fruit extracts (acetone: toluene:ethyl acetate) (1:1:1)

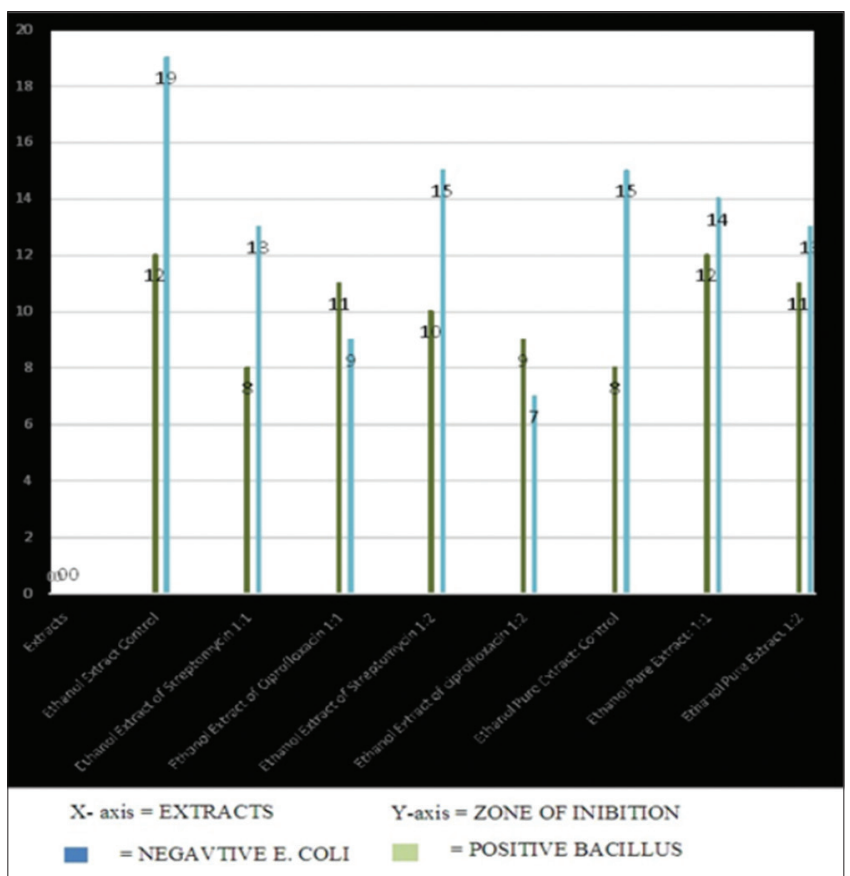

Fig. 2: Graphical representation of antimicrobial activity

maximum zone of inhibition was found to be $12 \mathrm{~mm}$ for ethanol control, $8 \mathrm{~mm}$ for ethanol pure extract control, $12 \mathrm{~mm}$ for ethanol pure extract (1:1), $11 \mathrm{~mm}$ for ethanol pure extract (1:2), $8 \mathrm{~mm}$ for ethanol extract of streptomycin (1:1), $11 \mathrm{~mm}$ for ethanol extract of ciprofloxacin (1:1), $10 \mathrm{~mm}$ for ethanol extract of streptomycin (1:2) and $9 \mathrm{~mm}$ for ethanol extract of ciprofloxacin. Hence, antimicrobial activity of $D$. palmatus fruits extract had good output in Gram-negative bacteria and Gram-positive while compared to the standard (streptomycin and ciprofloxacin) and control in two different concentrations. The graphical representation of antimicrobial activity of D. palmatus is shown in Fig. 2. 
Table 5: Tail immersions method (analgesic activity)

\begin{tabular}{|c|c|c|c|c|c|c|c|c|}
\hline \multirow[t]{2}{*}{ Groups } & \multirow[t]{2}{*}{ Treatment } & \multicolumn{7}{|c|}{ Reaction time in seconds (mean and SEM) } \\
\hline & & $0 \mathrm{~min}$ & $5 \mathrm{~min}$ & $10 \mathrm{~min}$ & $15 \mathrm{~min}$ & $20 \mathrm{~min}$ & $25 \mathrm{~min}$ & $30 \mathrm{~min}$ \\
\hline Control & No drug & $1 \pm 0$ & $2 \pm 0.632$ & $1 \pm 0$ & $1.6 \pm 0.6$ & $1 \pm 0$ & $3 \pm 0.734$ & $1 \pm 0$ \\
\hline Test 1 & D.P (100 mg) & $1 \pm 0$ & $3 \pm 0.547$ & $5 \pm 0.774$ & $9 \pm 0.447$ & $6 \pm 0.632$ & $5.2 \pm 0.3$ & $3 \pm 0.774$ \\
\hline Test 2 & D.P (200 mg) & $4 \pm 0.632$ & $7.2 \pm 0.86$ & $11.4 \pm 1.93$ & $13.4 \pm 1.63$ & $7.6 \pm 0.871$ & $7.6 \pm 0.78$ & $2 \pm 0.316$ \\
\hline Test 3 & D.P (400 mg) & $3 \pm 0.547$ & $5.8 \pm 0.66$ & $5.4 \pm 0.509$ & $7.6 \pm 0.748$ & $5.8 \pm 1.02$ & $3.8 \pm 0.2$ & $2.8 \pm 0.66$ \\
\hline
\end{tabular}

The data represent the mean \pm SEM $(n=8) .{ }^{*} \mathrm{p}<0.05,{ }^{* *} \mathrm{p}<0.01$, compared to corresponding control. Control: 1 ml $/ \mathrm{kg}$ (p.o); standard drug: Aspirin test drug: Ethanolic extract of Diplocyclos palmatus

Table 6: Tail clip method (analgesic activity)

\begin{tabular}{|c|c|c|c|c|c|c|c|c|}
\hline \multirow[t]{2}{*}{ Groups } & \multirow[t]{2}{*}{ Treatment } & \multicolumn{7}{|c|}{ Reaction time in seconds (mean and SEM) } \\
\hline & & 0 min & $5 \min$ & $10 \mathrm{~min}$ & $15 \min$ & $20 \min$ & $25 \mathrm{~min}$ & $30 \mathrm{~min}$ \\
\hline Control & No drug & $1 \pm 0$ & $2 \pm 0.632$ & $1 \pm 0$ & $1.6 \pm 0.6$ & $1 \pm 0$ & $3 \pm 0.775$ & $1 \pm 0$ \\
\hline Standard & Aspirin & $3 \pm 0.775$ & $8 \pm 2.35$ & $11 \pm 1.76$ & $14 \pm 1.82$ & $10.4 \pm 1.03$ & $8 \pm 2.35$ & $3 \pm 0.837$ \\
\hline Test 1 & D.P (100 mg) & $1 \pm 0$ & $5 \pm 0.775$ & $6 \pm 0.632$ & $10 \pm 0.707$ & $7 \pm 1.38$ & $4 \pm 0.632$ & $2 \pm 0.316$ \\
\hline Test 2 & D.P (200 mg) & $2 \pm 0.316$ & $5.9 \pm 0.98$ & $6.7 \pm 0.663$ & $8.3 \pm 0.831$ & $9.1 \pm 2.65$ & $2.8 \pm 0.917$ & $2 \pm 0.316$ \\
\hline Test3 & D.P (400 mg) & $2 \pm 0.316$ & $8 \pm 1.34$ & $11 \pm 1.67$ & $10 \pm 0.707$ & $10 \pm 0.707$ & $8.2 \pm 1.2$ & $2 \pm 0.418$ \\
\hline
\end{tabular}

Data presented as mean \pm SEM, $\mathrm{n}=8$ for all groups. ${ }^{* *} \mathrm{p}<0.01$ (aspirin) ${ }^{*} \mathrm{p}<0.05$. $\mathrm{P}<0.05$ taken as significant

Table 7: Radiant heat method (analgesic activity)

\begin{tabular}{|c|c|c|c|c|c|c|c|c|}
\hline \multirow[t]{2}{*}{ Groups } & \multirow[t]{2}{*}{ Treatment } & \multicolumn{7}{|c|}{ Reaction time in seconds (mean and SEM) } \\
\hline & & $0 \mathrm{~min}$ & $5 \mathrm{~min}$ & $10 \mathrm{~min}$ & $15 \mathrm{~min}$ & $20 \mathrm{~min}$ & $25 \mathrm{~min}$ & $30 \mathrm{~min}$ \\
\hline Control & No drug & $1 \pm 0$ & $2 \pm 0.632$ & $1 \pm 0$ & $1.6 \pm 0.6$ & $1 \pm 0$ & $3 \pm 0.775$ & $1 \pm 0$ \\
\hline Standard & Aspirin & $3 \pm 0.775$ & $9 \pm 0.447$ & $9 \pm 0.447$ & $10 \pm 0.837$ & $10 \pm 0.837$ & $7 \pm 1.382$ & $2 \pm 0.316$ \\
\hline Test 1 & D.P (100 mg) & $1 \pm 0$ & $4 \pm 0.632$ & $8 \pm 1.1$ & $11 \pm 1.76$ & $6 \pm 0.837$ & $5 \pm 0.548$ & $2 \pm 0.316$ \\
\hline Test 2 & D.P (200 mg) & $2.9 \pm 0.678$ & $7.8 \pm 1.71$ & $11.3 \pm 1.67$ & $14 \pm 1.82$ & $9.5 \pm 0.707$ & $8.54 \pm 0.694$ & $3 \pm 0.548$ \\
\hline Test3 & D.P (400 mg) & $2 \pm 0.316$ & $5.5 \pm 1.1$ & $7 \pm 1.38$ & $8.2 \pm 1.11$ & $9.1 \pm 0.447$ & $3 \pm 0.832$ & $2 \pm 0.316$ \\
\hline
\end{tabular}

Per oral administration of vehicle and crude extract, radiant heat intensity was 6 amp. ${ }^{* *} \mathrm{p}<0.01$ : Very significant, ${ }^{*} \mathrm{p}<0.05$ : Significant, Number of animals $\mathrm{n}=5$, values are expressed as mean \pm SEM, SEM: Standard error of mean, D. palmatus fruits

For analgesic activity, the plant extract demonstrated adequate results on albino mice when compared with standard aspirin. This analgesic activity was determined using three different methods, that is, tail immersion, tail clip, and radiant heat method. The results of tail immersion method are summarized in Table 5.

In a similar way, the results of tail clip method are summarized in Table 6.

The results of radiant heat method were summarized Table 7 .

\section{DISCUSSION}

To investigate the medicinal value of plants is an ancient concept and for centuries people have been trying to develop various drugs from plants which have potent activity and less side effects. In literature, it has been indicated that medicinal plants are the foundation of conservative medicine and the activity of plant extract is due to different chemical agent in the extract which was classified as active compounds [18]. In plants, various phytochemical constituents such as tannins, flavonoids, alkaloids, and several other aromatic compounds are available and secondary metabolites of plants that serve as safeguarding mechanisms against predation by many microorganisms, insects, and herbivores and act as a phytoprotectants and respond to environmental stress condition [19]. This may, therefore, explain the demonstration of antimicrobial activity by the fruit extracts of D. palmatus. It has been also reported that $D$. palmatus fruit extract shows antimicrobial property due to the presence of secondary metabolites such as phenols and flavonoids.

The demonstration of antibacterial activity against both Gram-positive and Gram-negative bacteria may be indicative of the presence of broad- spectrum antibiotic compounds [20]. Results of this study demonstrated that the Gram-negative bacteria ( $E$. coli) were more resistant than Grampositive bacteria (B. subtilis). It was observed that the plants in different regions of the world had antimicrobial and analgesic effect. This may be due to many factors such as the effect of climate, soil composition, age and vegetation cycle stage, on the quality, quantity, and composition of extracted product, and different bacterial strains [21].D. palmatus fruits are more significant when compared with standard drug ciprofloxacin and streptomycin [2]. Due to presence of lipopolysaccharide layer in outer membrane of Gram-negative bacteria, its hydrophobicity acts as a strong permeability barrier against hydrophobic molecules [22]. Hydrophobic molecules can pass through cell wall of Gram-positive bacteria easier than the Gram-negative bacteria because the cell wall of the Gram-positive bacteria contained only peptidoglycan [23]. Ethanolic extract fruits of D. palmatus more significant while compare to the other parts of D. palmatus in antimicrobial activity [24].

The analgesic properties of the fruit of D. palmatus were studied using three laboratory models, which allowed the assessment of responses to chemically induced pain stimulus (aspirin). The radiant heat method is the most reliable test for analgesic. The analgesic activity of the ethanolic extract of D. palmatus fruit produced significant graded dose effects in three models employed, namely tail clip, tail immersion, and radiant heat method, in compare to the other parts of D. palmatus [25].

\section{CONCLUSION}

The antimicrobial activity of the ethanolic extracts of D. palmatus fruits against the test organisms showed significant antimicrobial activity as proven by testing against the microorganisms that are B. subtilis (Gram- 
positive bacteria) and E. coli (Gram-negative bacteria). Analgesic activity on different groups of albino mice suggested that the plant also possess significant analgesic activity. The analgesic and antimicrobial activity of the ethanolic extract of D. palmatus fruits are more significant compared to the other parts of D. palmatus. Hence, the study concludes that plants have both analgesic and antimicrobial activity and, therefore, with it can be used for various therapeutic purposes and further analysis.

\section{ACKNOWLEDGMENTS}

We would like to express our sincere thanks to MAK College of Pharmacy for providing the required facilities and BSI (Deccan Regional Centre - Hyderabad) for valuable support in authentication of drug. We are highly indebted to the Institutional Committee of MAK College of Pharmacy for providing laboratory and animal facility.

\section{AUTHORS' CONTRIBUTION}

Mr. Ramkishan J and Mr. Venkanna P are involved in the plant identification, methodology and carried the experimental part. Dr. Khaja Zeeyauddinn is involved in the pharmacology related work and overall design of work. Dr. Sateesh Kumar Vemula is involved in microbiological testing, literature procurement, and manuscript writing.

\section{CONFLICTS OF INTEREST}

The authors declare that they have no conflicts of interest.

\section{REFERENCES}

1. Available from: http://www.tropical.theferns.info/viewtropical.php?id= Diplocyclos+palmatus.

2. Gautam VP, Aslam PR, Bharti KU. Diplocyclos palmatus: A psychopharmacological review. Int J Res Pharm Chem 2013;3:157-9.

3. Tikkinen KA, Leinonen JS, Guyatt GH, Ebrahim S, Järvinen TL. What is a disease? Perspectives of the public, health professionals and legislators. BMJ Open 2012;2:e001632.

4. Misra A, Shukla PK, Kumar B, Niranjan A, Rawat AK, Srivastava S, et al. Simultaneous-HPLC quantification of phenolic acids in traditionally used ayurvedic Herb Diplocyclos palmatus (L.) Jeffry. Pharm J 2017;9:483-7.

5. Germplasm Resources Information Network. Diplocyclos palmatus (L.) C. Jeffrey. Available from: http:/www.ars-grin.gov/cgi-bin/npgs/ html/taxon.pl?409855.

6. Michel H. Sorting Diplocyclos Names. Multilingual Multiscript Plant Name Database - A Work in Progress. School of Agriculture and Food Systems. The University of Melbourne; 2010. Available from: http:// www.plantnames.unimelb.edu.au/Sorting/Diplocyclos.html.
7. Adebooye OC. Solanecio biafrae (Oliv. and Hiern) C. Jeffrey In: Grubben GJ, Denton OA, editors. PROTA 2: Vegetables/Légumes. Wageningen, Netherlands: [CD-Rom]. PROTA; 2004.

8. Bhavani MB. Preliminary phytochemical investigation on a few Cucurbitaceae plants. Int J Pharm Res Bio Sci 2013;2:529-6.

9. Mukherjee PK. Quality Control of Herbal Drugs. New Delhi: Business Horizons; 2002

10. Agrawal SS, Paridhavi M. Herbal Drug Technology. $2^{\text {nd }}$ ed. Mumbai: Dattani Book Agency; 2014

11. Renuka K, Devi VR, Subramanian SP. Phytochemical screening and evaluation of in vitro antioxidant potential of immature palmyra palm (Borassus flabellifer Linn) fruits. Int J Pharm Pharm Sci 2018;10:77-83.

12. Maragathavalli S, Brindha S, Kaviyarasi NS, Annadurai B, Gangwar SK. Anti-microbial activity in leaf extract of neem (Azadirachta indica linn.). Int J Secur Netw 2012;3:110-3.

13. Available from: http://www.shodhganga.inflibnet.ac.in/bitstream/ 10603/2520/11/11 chapter\%204.pdf.

14. Jayasree $\mathrm{P}$, Thiruchelvi R, Balashanmugam $\mathrm{P}$. Evaluation of antibacterial, antioxidant, and anticancer potentials from marine red algae Gracilaria corticata. Asian J Pharm Clin Res 2018;11:347-50.

15. Kulkarni SK. Hand Book of Experimental Pharmacology. $4^{\text {th }}$ ed. New Delhi: Vallabha Prakashan Publication; 2012. p. 165-84.

16. Thiombiano EM, Ouedraogo N, Kiendrebeogo M, Lompo M. Antiinflammatory, analgesic and antioxidant activities of hydro-acetonic extract from Wissadula amplissima var. Rostrata (shum. And thonn.) R. E. Fries. Int J Pharm Pharm Sci 2018;10:113-7.

17. Stahl E. Thin-layer Chromatography-a Laboratory Handbook. $2^{\text {nd }}$ ed. Berlin, Heidelberg: Springer-Verlag; 1969. p. 256-9.

18. Fransworth NR. Ethanopharmacology and Drug Discovery. Chicheter: Ciba Foundation Symposium Wiley; 1994. p. 42-9.

19. Lutterodt GD, Ismail A, Basheer RH, Baharudin HM. Antimicrobial effects of Psidium guajava extract as one mechanism of its antidiarrhoeal action. Malays J Med Sci 1999;6:17-20.

20. Marjorie MC. Plant products as antimicrobial agents. Clin Microbiol Rev 1999;2:564-82.

21. Masotti V, Juteau F, Bessière JM, Viano J. Seasonal and phenological variations of the essential oil from the narrow endemic species Artemisia molinieri and its biological activities. J Agric Food Chem 2003;51:7115-21.

22. Gupta S, Singh A. Antimicrobial, analgesic and anti - Inflammatory activity reported on Tamarindus indica Linn root extract. Pharm J 2017;9:410-6.

23. Palmer S, Stewart AJ, Fyfe L. Antimicrobial properties of plant essential oils and essences against five important food-borne pathogens. Lett Appl Microbio 1998;6:118-22.

24. Nikaido H, Vaare M. Molecular basis of bacteria outer membrane permeability. Microbio Rev 1985;49:1-32.

25. Kadam P, Bodhankar SL. Analgesic and anti-inflammatory activity of seed extract of Diplocyclos palmatus $L(C)$. Jeffrey. Int J Pharm Bio Sci 2013;4:970-8. 